\title{
Thematic Study of Siraiki Naat
}

\author{
${ }^{a}$ Muhammad Abu Bakar, ${ }^{\text {b }}$ Muhammad Mumtaz Khan \\ a PhD Scholar, Department of Siraiki, The Islamia University of Bahawalpur, Pakistan \\ Email: abubakarbwp9@gmail.com \\ ${ }^{\mathrm{b}}$ Assistant Professor, Department of Siraiki, The Islamia University of Bahawalpur, Pakistan \\ Email: mumtaz.khan@iub.edu.pk
}

\begin{tabular}{|c|c|}
\hline ARTICLE DETAILS & ABSTRACT \\
\hline $\begin{array}{l}\text { History: } \\
\text { Accepted } 30 \text { April } 2021 \\
\text { Available Online June } 2021\end{array}$ & \multirow{3}{*}{$\begin{array}{l}\text { With the advent of Islam, Naat recitation was started. Siraiki Naat } \\
\text { recitation also has a thousand years of history. Love to rasool (PBUH), } \\
\text { event miraj, Sarapa nigari, the birth of Prophet (PBUH), miracles, } \\
\text { morality, Mercy for the whole universe, and Ghazwat is prominent in } \\
\text { major naat subjects, The siraiki poet begins his poetry with the divine } \\
\text { and naat-e-Rasool (PBUH) and in his own style and his own words, He } \\
\text { seeks to describe the Holly prophet (PBUH) and considers it an essential } \\
\text { part of his faith. The majority of Siraiki poetry consists of the praise of } \\
\text { the Holy Prophet and this series will continue till the Day of Judgment. } \\
\text { The thematic study of siraiki naat is presented in the research paper } \\
\text { under discussion. }\end{array}$} \\
\hline $\begin{array}{l}\text { Keywords: } \\
\text { Naat Recitation, Subjects, } \\
\text { Judgment, Holy Prophet (Pbuh), } \\
\text { Sheeda Kaka Khail, Sarapa Nigari }\end{array}$ & \\
\hline $\begin{array}{l}\text { JEL Classification: } \\
P_{36}\end{array}$ & \\
\hline DOI: $10.47067 /$ real.v4i2.159 & $\begin{array}{l}\text { (C) } 2021 \text { The authors. Published by SPCRD Global Publishing. This is an } \\
\text { open access article under the Creative Commons Attribution- } \\
\text { NonCommercial } 4.0\end{array}$ \\
\hline
\end{tabular}

Corresponding author's email address: abubakarbwp9@gmail.com

\section{Introduction}

The poetic praise of the Holy Prophet (PBUH) is called "Naat". It is a fact that the Holy Prophet (PBUH) has been praised the most in the whole world. When it comes to the topics of Naat, they are directly related to the Holy Prophet (PBUH). Now Naat recitation has taken the form of a regular genre. Naat has been written continuously for the last fourteen hundred years and even today its popularity has not diminished. Naat collections are being printed in every language and this process of Naat recitation will continue till the Day of Judgment. Regarding the capacity of Naat subjects, Sheeda Kakakhel writes:

A large part of Naat is Holy Prophet(PBUH) life, teachings, virtue and superiority, his being the last of the prophets, proclamation of prophethood, migration to Madinah, conquests, the event of Ascension, his human sympathy and grief, forgiveness, intercession, Many subjects are included in the Naat based on the desire to visit the Holy Shrine, his clothing and food, his beautiful attire and his undying love for the Holy Prophet. " (Khail, 2007) 
Speaking of Siraiki Naat recitation, it is an asset of Siraiki poetry which has a unique place in literature in terms of capacity, eloquence and sweetness of Siraiki language. Regarding the subjects of Siraiki Naat, Dr. Nasrullah Khan Nasir Says:

Most of the subjects of Naat in Siraiki language are Miraj, Sarwar-eQuneen, Sarapa, Huliya Mubarak, Durood-e-slam, longing to visit the Holy Shrine, longing for closeness to the Holy Prophet, The support of his forgiveness and the hope of his grace. " (Nasir, 2007)

The greatest theme of Naat is the love of the Prophet (peace and blessings of Allah be upon him). Love, affection and devotion to the Holy Prophet (PBUH) is an essential part of every Muslim's faith and the basic foundation of Islam. No Muslim can become a Muslim without believing that the Holy Prophet (PBUH) is the last of the prophets. Poets demonstrate his true love for the Holy Prophet (PBUH) in his poetry and prove to be his true Muslim. See a glimpse of the love of the Prophet (PBUH) in Siraiki poetry:

Jy Bhuldy hin Bhulin mekon Amma Abba tay Bhainein Bhai $\mathrm{Na}$ main mardiyan talak wisaran ya Rasol Allah Nahen koi lorr banglay di nah Raqbay di nah caran di Mahil hik ishq tedy da usaran ya Rasol Allah (Dilchasp, 2009)

This world was created for the sake of the Holy Prophet (PBUH), therefore he is called the cause of the creation of the universe. The appearance of the Prophet (peace be upon him) in the world led to a great revolution. The light of his prophethood in the world led to the eradication of the darkness of ignorance. Therefore, his birth is considered to be one of the most important events in human history. It is narrated with deep emotion. Every poet has described the blessed birth of the Holy Prophet (PBUH) in his own way. As one Siraiki poet says:

\section{Gul Gulzaran Bagh Baharan amad sohnay di}

Barhan Rabiul Awal sohnra war somwar hy aya (Shaheen, 2014)

The Prophet (peace and blessings of Allah be upon him) is called Shafi'i al-Mahshar. Only he will be able to intercede for the forgiveness of his followers on the day of reckoning. This is also mentioned in the Qur'an and Hadith. Siraiki poets have proudly included the attribute of the Prophet (PBUH) as the intercessor of the Day of Judgment in their poetry and have also expressed their desire to benefit from this attribute of the Holy Prophet (PBUH) on the Day of Resurrection. A Siraiki poet says in this regard:

Tamam Ummatian kitay mehshar dehary Khuda kon manawan Muhammad da kam hay (Gulshan, 2014)

Every Muslim desires to visit the Holy Shrine of the Holy Prophet, kiss the nets of the Holy Prophet's shrine, walk the streets of Madinah and go wherever the blessed footsteps of the Holy Prophet fall. This love and devotion to Madinah is present in the heart of every Muslim. Siraiki poets also express their love for the Holy Shrine of the Prophet (peace be upon him) in words. 


\section{Ya Nabi ya Nabi sohna roza dekha Main ajiz di sun aj eha iltija Tedi rehmat da sohna talabgar han Ay tan theek hy jo main Bahon gunahagar han Aj tan aasi di sun ya Nabi toon sada (Baqir, 2013)}

Sarapa Nigari has also been an important subject of Naat. In Sarapa of Prophet(PBUH) head, hair, cheeks, hand, foot, face, eyes etc, every organ of the body is described with love and devotion. Sarapa nigari has always been a big and popular subject is described by Even in Siraiki Naat. Siraiki poets express their love and devotion to the Holy Prophet (PBUH) in their own way. See an example of this:

\section{Sohni sorat akh mastani \\ Kul kainat tedi dewani (Sabir, 2017)}

Allah and his angels send blessings on the Holy Prophet (peace and blessings of Allah be upon him), so he has commanded his slaves to send blessings on the Holy Prophet (peace and blessings of Allah be upon him). Therefore, every Muslim not only obeys the divine command by sending blessings and peace upon the Holy Prophet, but also considers it as a means of salvation for himself. The importance of Durood o Salam has also been beautifully explained in Siraiki Naat. Here is a lion in this regard:

$$
\begin{aligned}
& \text { Safeer Rab da wazir aya darood Bhejo salam Bhejo } \\
& \text { Ameer azli ameer aya darood Bhejo salam Bhejo (Lashari, }
\end{aligned}
$$

Every Muslim considers the Holy Prophet (peace and blessings of Allah be upon him) as his greatest sympathizer and benefactor. There is a person who seeks help from Allah through the Holy Prophet (peace and blessings of Allah be upon him) for the solution of any problem or if anyone prays, it is not rejected. Therefore, siraiki poets also look forward to the Prophet (peace be upon him) in any trouble or difficulty. See an example from the Siraiki Natia poetry in this regard:

Gunhagaran la charan koon sahara Mustafa da hay Jehra Mukhtar e kul hy saeen shafi Roz e jaza da hay Moonjha asloon nah thi yara nah hargiz dil lahaveen toon Muhammad Mustafa saeen aasra har bay nawa da hay Jigar da soze, dard e dil Bhanwain kai marz Bia howay (Faridi, 2008) Karainda Arbi saeen daroon har marz e la dawa da hay

The occurrence of an unnatural and irrational act at the hands of a prophet is called a "miracle". Allah Almighty had also blessed his beloved Prophet (peace be upon him) with many miracles. The revelation of the Holy Qur'an to the Holy Prophet is a miracle that will last till the Day of Judgment. Apart from this, many miracles such as ascension, reflection of the sun, walking of trees, reciting Durood of stones, springs flowing from the fingers of the Prophet (peace be upon him), animals talking to him and blessings in food on different occasions had given, These miracles are specially mentioned in Siraiki poetry. Poets express the greatness and glory of the Holy Prophet (PBUH) by narrating his 
miracles and thus express their deep devotion and attachment to him. Here are some examples of miracles from Siraiki poetry:

Taien pathren koon tarwa chhoriay taien kalmah vi parhwa chhoriay Bay mosmein phul ugwa chhoriay taien shajrain koon turwa chhoriay Kadh pani apnein anglien toon taien peyasen koon pilwa chhoriay Mahboob taiday darwzy tay kainat koon main jhukwa chhoriay Taien chan day tukray doo ketay taien sijh pichty walva chhoriay Bus Madni apni mansha tay taien kibla vi watva chhoriay

(Samunvi, 2018)

Arbi keevain mojzah dekhaey, pani pilay lashkar rajay Piyaly andar hath koon tikaey nehran chalaey Betha wahaey Lashkar tay theya ahsan hy sahib lolak lama da (Nadim,2013)

Allah Almighty has sent about one hundred and twenty four thousand prophets in this world and sent his beloved Hazrat Muhammad Mustafa (peace be upon him) as the first to be created and last as the last of the prophets. The chain of prophethood has ended after the Holy Prophet (peace be upon him) and now only the prophecy of the Holy Prophet (peace be upon him) will remain valid till the Day of Resurrection. Every poets has made this honor of the Prophet (PBUH) the subject of Naat and he has expressed his devotion by describing the glory of Prophet (PBUH) as a Siraiki poet says:

Noor nirala, Arbi wala saray jag vich hoya ujala

Shah kul hy khatmul rusal walail deyan zulfan wala (Shah, 2011)

Allah Almighty sent the Prophet (peace and blessings of Allah be upon him) as a mercy to the worlds and it is also mentioned in the Holy Qur'an. The Holy Prophet (peace and blessings of Allah be upon him) has been a mercy for the worlds till the Day of Resurrection, and this honor has come only to the Holy Prophet (peace and blessings of Allah be upon him) out of one hundred and twenty-four thousand prophets. The Holy Prophet (peace be upon him) not only held the position of growth and guidance and benevolence of humanity in this world, but on the Day of Judgment he will also intercede with Allah for the salvation of his followers. The whole life of the Holy Prophet (peace and blessings of Allah be upon him) was a practical example of the merciful. Siraiki Natia poets in their poetry have specifically clarified this attribute of the Holy Prophet (PBUH) and it would not be out of place to say that this subject has been the favorite of every poet. See a poem from Siraiki Natia poetry in this regard:

$$
\begin{aligned}
& \text { Toon hain sohnan Rehmatul lil Alamin } \\
& \text { Kul jahanein day andar teda jamal (Saeedi, 2011) }
\end{aligned}
$$

The Holy Prophet (peace and blessings of Allah be upon him) took part in many battles in his blessed life and fought the infidels with great courage and bravery. In these battles, many of the Companions who fought the infidels alongside the Holy Prophet (PBUH) drank the cup of martyrdom. He was also wounded in the battle of Uhud. In the same battle, his blessed teeth were also martyred, but for the sake of Islam, he and his companions showed great steadfastness, courage and bravery. This attribute of the Holy Prophet (peace be upon him) has also been made the subject of his Naat by Siraiki poets. For example, see this poem: 
Edon haq tray so tehran ha odoon dushman da lashkar ha Khuda di mil madad gai hai Nabi sohnay jo farmaya (Sohani, 2018)

The event of Ascension is a miracle of the Holy Prophet (PBUH) on which the world is still amazed. Allah Almighty gave his beloved Prophet Muhammad Mustafa (peace be upon him) his vision directly. Hazrat Jibril Amin came to earth and took the Holy Prophet (PBUH) to Al-Aqsa Mosque sitting on a Buraq. He led all the Prophets there. Then you went to the sky, there were seven skies, there met the other many Prophets. At the same time, he was shown Paradise and Hell. Then he went beyond Sidra Al-Muntaha and met Allah directly. On this occasion Allah almighty gave you the gift of prayers. Time has stopped and distances have narrowed, meaning that he has transcended time and space, and this event is still a challenge to the human intellect. On this occasion, Hazrat Abu Bakar Siddiq confirmed the incident with full conviction and was honored with the title of "Siddiq". The poets have made this incident the subject of their Naat and described his closeness and greatness to Allah. In this regard, Ali Bakhsh Bheet says:

\section{Jadan aye dahrti tay lag giyan baharan Khabar hik sunai sohnay aa tay yaran Hiki rat vich sal langh gay atharan Safar wang baneya sara hik Bilhangay (Bhait, 2018)}

Allah Almighty has bestowed many honors on his beloved Prophet Muhammad Mustafa (peace be upon him) in this way, but by making him the butler of Kausar Pool, He has bestowed upon him a special virtue. On the Day of Judgment, when the soul will be in the realm of the soul, everyone will have their own. This miracle has been bestowed only on the Holy Prophet (peace and blessings of Allah be upon him) among all the Prophets, which is also mentioned in the Qur'an. Every Muslim desires to have the happiness of drinking the water of the pool of Kausar from the blessed hands of the Holy Prophet (PBUH). Siraiki poets put this wish into words, then something like this comes of poetry:

Mehshar day deenh piasy saray teday taien faryad karesin

Teday hath vich janat sohnran teday hath vich kousar saeen (Multani, 1988)

The life of the Holy Prophet (peace and blessings of Allah be upon him) is a good example for Muslims to come to the Day of Resurrection. Allah Almighty has endowed him with innumerable moral and spiritual attributes which by his practical expression he has laid down the principles of living a glorious and successful life for the people till the Day of Resurrection. His biography is a practical description of the Holy Qur'an, so he said in his last sermon that I am leaving two things between you, one is the Qur'an and the other is the Sunnah and following them is the key to success. Mention of the virtues of the Holy Prophet (peace be upon him) has also been a favorite subject of our poets. As Riaz Hussain Iram writes:

Sabaq dunia koon a ditta amanat da sadaqat da

Tedi har hik ada hay pai nirali ya Rasol Allah (Iram, 2007)

Allah mentions the Prophet (peace and blessings of Allah be upon him) with many titles in the Holy Qur'an, but Muslims believe that if prayers were asked for through the Prophet's titles and names, Allah would accept it. Some of the Holy names of the Holy Prophet (PBUH) are also mentioned in the heavenly books and scriptures, as in the Torah, the Holy Prophet (PBUH) is mentioned by the Holy 
name "Ahmad". In the Quran has been called Al-Shakir Al-Mursal, Al-Mubin, Al-Dhuha, Al-Mudasir, Khatam Al-Naba'een. These names of the Holy Prophet (peace be upon him) have also been specially mentioned by the Siraiki poets in their Naat. See this lion for example:

Raof aur Raheem hin laqab pak jenday tay Hamid tay Mehmood Quran dasainday Khuda ap koon kud Muhammad akhenday, dasa aqal di wat ithan kerhi ja hay Muhammad Sirajan Muniran Baseran Muhammad Bashiran Naziran khabiran Ay Sumun tay Bukmun tay Omyo Sharera toon keewain akhenden Muhammad bhira hay Hay awal Muhammad tay akhir Muhammad, hay Batin Muhammad tay Zahir Muhammad Hay Hazir Muhammad tay Nazir Muhammad thi Azhar kran main keewain luk luka hay

(Azhar, 1997)

In short, the Siraiki poets have expressed their love and devotion to the Holy Prophet (PBUH) by describing his virtues, miracles and characteristics, and this process will continue till the Day of Judgment.

\section{References}

Azhar, M. K. (1997). Dewan-e-Azhar. Kaleem Art Press Multan , 52.

Baqir, A. H. (2013). Sabar Da Phall. Jhok Publishers Multan , 41.

Bhait, A. B. (2018). Dewan-e-Ali Bakhsh Bhait. Rang-e-Adab Publications Karachi , 58.

Dilchasp, F. M. (2009). Dewan-e-Dilchasp. Dilchasp Siraiki Sangat Jindo Pir Kamal Liaquat Pur , 31.

Faridi, F. H. (2008). Nit Tangh Talab. Sanwal Siraiki Adbi Academy Dera Shams Rahimyar Khan , 11.

Gulshan, A. (2014). Qainaat Da Waris. Jhok Publishers Multan , 58.

Iram, R. H. (2007). Noor Di Barish. Jhok Publishers Multan , 48.

Khail, S. M. (2007). Urdu Main Ghair Islami Anasir Ka Tehqeeqi Tanqeedi Mutalia. Department Urdu Univesrity of Peshawar, 3.

Lashari, S. (2002). Noor Gar. Safeer Siraiki Adbi Sangat Mehrab wala, 33.

Multani, U. (1988). Madni Saeen Sultan. Siraiki Ishaati Idara Multan , 49.

Nadim, F. U. (2013). Dewan-e-Nadim. Nadim Siraiki Adbi Sangat Muzaffar Garh , 132.

Nasir, D. N. (2007). Siraiki Shairi Da Irtika . Siraiki Adabi Board Multan , 173.

Sabir, F. (2017). Jan-e-Janan. Tehzeeb International Publicationers Bahawalpur , 65.

Saeedi, M. M. (2011). Mitha Meem Muhammad. Jhok Publishers Multan , 74.

Samunvi, S. (2018). Saya Na Sani. Jhok Publishers Multan , 70.

Shah, R.-e.-A. (2011). Daan Faizan. Jhok Publishers Multan , 29.

Shaheen, N. A. (2014). Biaz-e-Ishiq. Fareed Foram Bahawalpur , 26.

Sohani, Q. (2018). Tajali. Nasir Publications Dera Ghazi Khan , 60. 